UnB

\title{
Quem (não) tem medo da literatura negra? O amor negro no combate ao genocídio do branqueamento
}

\section{Resumo:}

Historicamente construiu-se a ideia de que o cânone literário é uma seleção baseada unicamente na qualidade do texto. Tal perspectiva, além de ignorar as inegáveis relações de poder envolvidas no processo também acaba por engessar as possibilidades criativas de muitas/os artistas. Neste trabalho vamos discutir alguns aspectos desses conflitos, associados principalmente à importância da luta pela valorização da literatura negra não apenas como manifestação artística fundamental, mas também como instrumento de luta contra o genocídio da população negra, empreendido ora por meio da defesa do mito da miscigenação redentora, base da política de branqueamento da população brasileira desde o fim da escravidão, ora pela ideia de um nacionalismo homogêneo e comum a todas/os. Entendemos que a melhor forma de combater esse processo de extermínio é valorizando o amor e a família preta e somente a literatura é capaz de ressignificar os séculos de brutalização e animalização de corpos e afetos negros.

Palavras-chave:

Literatura negra, Amor, Genocídio, Miscigenação, Nacionalidade

\section{Abstract:}

Historically, the idea has been constructed that the literary canon is a selection based solely on the quality of the text. Such a perspective, in addition to ignoring the undeniable power relations involved in the process, also ends up hampering the creative possibilities of many artists. In this work we will discuss some aspects of these conflicts, mainly associated with the importance of the struggle for the valorization of black literature, not only as a fundamental artistic manifestation, but also as an instrument to fight the genocide of the black population, undertaken now through the defense of the miscegenation myth redemptive, the basis of the policy of whitening the Brazilian population since the end of slavery, now for the idea of a homogeneous nationalism common to all. We understand that the best way to combat this process of extermination is to value love and the black family and only literature is capable of giving a new meaning to the centuries of brutalization and animalization of black bodies and affections.

\section{Keywords:}

Black literature, Love, Genocide, Miscegenation, Nacionality 


\section{Introdução}

A importância política e social da literatura é inquestionável e, atualmente, já é comum o discurso de que essa é uma manifestação essencialmente humana, não apenas o desejo e até a necessidade, segundo Candido (2004) de viver momentos de fabulação que poucas artes conseguem proporcionar tanto quanto a literatura, mas também o impulso incontrolável de produzir literatura. No entanto, a realidade concreta e material do universo literário ainda destoa dessa tendência de pensamento. Segundo Abreu,

Para que uma obra seja considerada Grande Literatura, ela precisa ser declarada literária pelas "instâncias de legitimação". Essas instâncias são várias: as universidades, os suplementos culturais dos grandes jornais, as revistas especializadas, os livros didáticos, as histórias literárias etc. (Abreu 2006: 40)

Diante disso, é fundamental pensarmos quais são os critérios utilizados para selecionar textos e autoras/es para compor o cânone. Embora o discurso corrente seja o de avaliar unicamente a qualidade do texto, veremos que há muitos interesses e disputas envolvidas nesses processos e, quando inserimos o elemento racial na equação, o cálculo torna-se ainda mais desafiador.

A valorização da literatura negra tem sido uma pauta recorrente das lutas do Movimento Negro, pensando na Lei 10.639/2003, por exemplo, essa questão já deveria ter sido superada há tempos e essa produção fazer parte dos documentos de instâncias de legitimação do cânone, como a escola. No entanto, ainda notamos muita dificuldade para ter, até mesmo, o reconhecimento de muitas dessas obras como literárias por parte dessas mesmas instâncias.

Este artigo pretende problematizar o medo que a literatura negra causa. Por que, afinal, é mais interessante para a classe dominante que textos potentes e capazes de incentivar o senso crítico e a luta política sejam lidos como documentos históricos e sociais e não como ficção ou literatura de prazer? Qual é a grande ameaça que ter um repertório rico de obras literárias de autoria negra representa?

Veremos ao longo deste trabalho que alguns aspectos fundamentais para a consolidação do modelo burguês, capitalista e cristão, de sociedade estão alicerçados e dependem totalmente da submissão de povos não brancos. A construção de uma identidade baseada em valores eurocêntricos e capaz de apagar outras possibilidades de organização e sociabilidade é um desses pilares. Outra importante estratégia é o genocídio ou assimilação desses povos, o mito da miscigenação redentora, pautado no discurso da selvageria negra, por exemplo, tem exercido importante papel para desqualificar a família negra e, consequentemente, exterminar, aos poucos, o fenótipo negro, como nos lembra Abdias Nascimento:

O processo de mulatização, apoiado na exploração sexual da negra, retrata um fenômeno de puro e simples genocídio. Com o crescimento da população mulata a raça negra está desaparecendo sob a coação do progressivo clareamento da população do país. E isto foi recebido com elogios calorosos e grandes sinais de alívio otimista pela preocupada classe dominante. (Nascimento 1978: 69-70) 
Diante disso, a literatura assume diferentes papéis, a branca hegemônica reforçando, de diferentes formas, o discurso racista dominante, e a negra, apresentando respostas não apenas para a impossibilidade, sempre retratada na literatura hegemônica, de que negras/os possam vivenciar o amor entre si, mas também para o amor idealizado e totalmente distante da realidade que vem sendo vendido para toda a população.

Portanto, queremos mostrar que a literatura negra é uma fonte inesgotável de prazer, conhecimento e apreciação estética, mas também é uma arma fundamental para barrar essa forma tão ardilosa e terrível de genocídio do povo negro.

\section{0 cânone da margem: quando a periferia invade o centro}

Apesar dos avanços e indispensáveis questionamentos quanto ao cânone literário, interesses e ideologias envolvendo sua escolha, esse ainda é um tema central, sobretudo quando pensamos nas produções literárias não hegemônicas, produzidas nas periferias do capitalismo ou por grupos minoritários em todo o mundo. Quando pensamos na literatura negra, esse cenário torna-se ainda mais complexo, dadas as particularidades criadas pelo racismo e seu papel fundamental nas construções políticas, econômicas, sociais e culturais da modernidade.

Nesse sentido, importa fazer alguns apontamentos sobre a relação entre literatura e valor, também associada à meritocracia e à "qualidade" do texto e da linguagem, bem como aos critérios que, de fato, orientam, historicamente, a escolha do cânone literário. Segundo Eagleton (2006:14) literatura é um conceito que pode entendido como "qualquer tipo de escrita que, por alguma razão, seja altamente valorizada". Ainda de acordo com o autor, tal postura

tem uma conseqüência bastante devastadora. Significa que podemos abandonar, de uma vez por todas, a ilusão de que a categoria "literatura" é "objetiva", no sentido de ser eterna e imutável. Qualquer coisa pode ser literatura, e qualquer coisa que é considerada literatura, inalterável e inquestionavelmente Shakespeare, por exemplo -, pode deixar de sê-lo. Qualquer idéia de que o estudo da literatura é o estudo de uma entidade estável e bem definida, tal como a entomologia é o estudo dos insetos, pode ser abandonada como uma quimera. (idem: 16)

Talvez isso explique a resistência da crítica literária para baixar a ponte levadiça e deixar o novo entrar. A elite intelectual e econômica, responsável pala manutenção das tradições, não está preparada para renunciar ao controle e à estabilidade das ideias de imanência da qualidade literária em nome de aceitar a inegável mutabilidade daquilo que consideramos literatura em um ou outro momento histórico.

Abreu (2006), por sua vez, desconstrói, também, a ideia da imparcialidade da escolha do cânone com base em uma literariedade imanente ao texto, no entanto, após analisar alguns textos não (necessariamente) literários, a autora conclui que "a literariedade não está apenas no texto - os mais radicais dirão: não está nunca no texto - e sim na maneira como ele é lido" (idem: 29). Nesse sentido, segundo a autora, a definição de literatura, além de uma entidade instável, como aponta Eagleton, esconde o ato de selecionar e excluir com objetivo de separar 
Cadernos de Literatura Comparada

Quem (não) tem medo da literatura negra?

textos específicos de autoras/es específicas/os dos textos que realmente devem circular.

Além disso, ainda segundo Abreu, muitas vezes, a seleção de textos e autoras/es não se baseia em critérios linguísticos, textuais ou estéticos, pois textos com estruturas temáticas e linguística muito semelhantes podem ser classificados de forma diferente quanto à literariedade. Nesse sentido, a questão do valor (literário) tem mais a ver com posições políticas e sociais e menos com textos. A autora prova seu ponto de vista propondo uma consulta rápida aos livros de história da literatura à procura de mulheres, pessoas negras e pobres.

Embora sejam inegáveis os avanços dos estudos literários no sentido de incorporar essas produções ao cânone mundial, a histórica rejeição à humanidade de pessoas negras ainda provoca descrença e até uma certa aversão ao reconhecimento da produção literária negra como digna de ser imortalizada sob o título de canônica. Silva nos oferece um panorama interessante da postura de muitos setores e representantes da crítica literária e da sociedade diante da descoberta do imenso legado de autoras/es negras/os para a literatura brasileira:

O insólito é o resumo da pergunta, muitas vezes preconceituosa, frequentemente feita ao surgimento de cada um dos ativistas, intelectuais, escritores e processos histórico-sociais estudados aqui, por diferentes autores, críticos, jornalistas e intelectuais. Como eles foram possiveis? Um escritor nessas condições? Isso é literatura ou documento social? Na história literária brasileira, o escritor negro passou a ser visto como uma espécie de avis rara. (Silva 2013: 29, grifos do autor)

Conforme Assis (2021: 344) "podemos ver que surpresa e descrença ainda são reações comuns diante da possibilidade de pessoas negras e pobres produzirem literatura". O lançamento do livro Quarto de despejo, de Carolina Maria de Jesus, é um exemplo de como essa descrença, longe de sucumbir e convencer-se da importância e riqueza literária da autoria negra, desvela o racismo e o preconceito que ainda permeiam nossas noções e "preferências" estéticas. "Esta favelada, Carolina Maria de Jesus, escreveu um livro" (Jesus 1961: 34), assim foi apresentada a autora no letreiro da livraria Francisco Alves, onde seria lançado, em 1960, o livro que viria a ser um dos maiores best sellers do país.

A total ignorância da elite intelectual brasileira quanto à produção cultural de pessoas negras e pobres fica evidente nessas duras palavras de espanto, carregadas de estigmas e preconceitos, nada velados, diante da insólita realidade de que uma favelada seria capaz de escrever, expressar-se de maneira crítica e, principalmente, artística. ${ }^{1}$ Não por acaso, mesmo tendo sido um sucesso nacional e internacional de público e vendas, Carolina, até pouco tempo, estava praticamente esquecida nos espaços intelectuais, sobretudo literários. Tanto assim que, durante as comemorações de seu centenário (2014), as quais promoveram uma retomada de sua obra e de sua importância para a literatura nacional, não foram poucas as manifestações contrárias a leituras literárias de seu acervo, sobretudo de seu famoso diário.

Carolina foi um exemplo emblemático da resistência da historiografia e crítica literárias para expandir suas perspectivas sobre o cânone e acolher novas vozes e possibilidades de expressão literária. 
Infelizmente, esse estranhamento não se reduz à intelectualidade brasileira, o "problema" da mundialização da literatura ou da inegável percepção de que, nas palavras de Goethe, "a poesia é um bem comum da humanidade, e que ela se manifesta em toda parte e em todas as épocas em centenas e milhares de seres humanos" (Eckermann 2016: 228) vem provocando o pensamento ocidental pelo menos desde meados do século XIX, como vemos nas afirmações do escritor. Goethe reforça, ainda, a necessidade de ir além dos limites da literatura nacional, segundo ele, "a literatura nacional hoje já não significa grande coisa, é chegada a época da literatura mundial, e todos devem trabalhar no sentido de apressá-la" (ibidem).

Porém, a mudança identificada e até celebrada pelo autor não incluía renunciar ao monopólio das formas definidas pelo império para a chamada Alta Literatura. Logo após a empolgação verificada acima, um momento de ponderação fez-se necessário:

Mas também nessa apreciação do estrangeiro, não devemos nos prender a nenhum caso em particular e tomá-lo como modelo. Não devemos pensar que sejam os chineses, ou os sérvios, ou Calderón, ou os Nibelungos; se necessitarmos de algum modelo devemos sempre retornar aos gregos antigos, em cujas obras encontramos com frequência representado o belo ser humano. (ibidem; grifo do autor)

Se por um lado suas reflexões podem remeter à possibilidade de, a partir da literatura-mundial, como uma categoria de análise (WReC, 2020), os estudos literários se libertarem de qualquer impedimento de cunho nacionalista e superarem fronteiras geopolíticas e culturais, inclusive para pensar o cânone e as categorias de análise envolvidas em sua definição; por outro, demonstra as limitações do império para renunciar ao domínio sobre a cultura de suas eternas colônias. As análises de Said (2011) oferecem material importante para entendermos melhor os limites da postura de Goethe, bem como de boa parte da crítica literária, e a necessidade de pensarmos a inserção das produções culturais e, sobretudo, literárias, das periferias da capital, sempre perpassadas pelas relações de poder entre centro e periferia, Ocidente e não Ocidente, colonizador e colonizado. Segundo o autor,

teremos de levar em conta a persistente disparidade de poder entre o Ocidente e o não Ocidente, se quisermos entender bem formas culturais como o romance, o discurso etnográfico e histórico, certos tipos de poesia e ópera, formas nas quais abundam alusões a essa disparidade e estruturas nela baseadas. Prossegui argumentando que, quando departamentos supostamente neutros da cultura, como a literatura e a teoria crítica, convergem para a cultura mais fraca ou subordinada e a interpretam com a ideia de que existem essências imutáveis, europeia e não europeia, com narrativas sobre a posse geográfica e imagens de legitimidade e redenção, a consequência flagrante tem sido dissimular a situação de poder e ocultar até que ponto a experiência da parte mais forte se sobrepõe à da mais fraca, e estranhamente depende dela. (Said 2011: 302-303)

O autor aponta aspectos importantes para (re)pensarmos o papel da crítica literária em contextos políticos mais amplos. Em primeiro lugar, essa suposta neutralidade acaba por 
Cadernos de Literatura Comparada

Quem (não) tem medo da literatura negra?

naturalizar as características definidoras do cânone, tornando-as, portanto, inquestionáveis e invioláveis. Além disso, a interpretação da produção literária não hegemônica com base numa essencialização do europeu e do não europeu não só dissimula as relações desiguais de poder envolvidas no processo, como também massifica e até engessa as possibilidades criativas de diferentes culturas.

Carneiro (2005) nos lembra da importância dos processos de racialização para reforçar a hegemonia branca, caracterizada pela positivação da figura do branco (colonizador) por meio da negativação do negro (escravizado):

Temos em Foucault um eu que é dotado de razoabilidade, porque produziu o louco; de normalidade, porque produziu o anormal; e de vitalidade, porque inscreveu o Outro no signo da morte. [...] esse eu, no seu encontro com a racialidade ou etnicidade, adquiriu superioridade pela produção do inferior, pelo agenciamento que esta superioridade produz sobre a razoabilidade, a normalidade e a vitalidade. Podemos afirmar que o dispositivo de racialidade também será uma dualidade entre positivo e negativo, tendo na cor da pele o fator de identificação do normal, e a brancura será a sua representação. (idem: 42)

No contexto da crítica literária, essa mesma lógica funciona e historicamente foi bastante eficaz para manter a literatura negra distante das estantes e bibliotecas. Se pensarmos na essência europeia e não europeia, de que nos fala Said, e na superioridade branca, criada com base na ideia de uma suposta inferioridade negra, conforme Carneiro, retomando ainda a ressalva de Goethe sobre o lugar das literaturas não hegemônicas e a permanência da Grécia como referência para adentrar os muros do feudo literário branco, notamos que, a partir dessas perspectivas, a literatura negra não teria, jamais, espaço no cânone.

Pensando a partir de Carneiro, apenas por serem negras/os, essas/es autoras/es já estariam marcadas/os pelo estigma da negatividade, da loucura, da anormalidade e da morte. Além disso, serão eternamente vistas/os como estrangeiras/os, pois são descendentes de povos africanos escravizados, portanto, sempre serão lidas/os a partir da essência não europeia de que nos fala Said. Por fim, sendo não europeus, não podem ser herdeiras/os legítimas/os da herança cultural grega, tampouco representar o "belo ser humano" exaltado por Goethe.

Nesse sentido, voltando à reflexão proposta por Goethe, podemos dizer que é, antes de tudo, uma leitura bastante conveniente para aquele momento histórico, político e cultural, quando a presença, participação e integração política, social e econômica de povos não brancos em ambientes dominados, até então, pelo imperialismo europeu era inadiável e inevitável. Diante disso, era urgente propor teorias que limitassem esses espaços e acessos, de modo a manter o mínimo de ordem e controle sobre as mudanças em curso. Reconhecer a literatura como um bem essencialmente humano e, portanto, permitir e até apreciar amostras desse produto é um caminho aceitável, porém o cânone e a produção epistemológica que fundamenta os saberes, formas, estéticas e temas da literatura permanecem nas seguras, consolidadas e alvas mãos imperiais.

Nesse contexto, para fazer parte do seleto grupo do cânone literário era fundamental seguir as regras estabelecidas histórica, social e economicamente pelos grupos dominantes ou oferecer 
conteúdos que agradassem a esse público. Novamente Carolina e seu grande e, para olhos colonizados e enevoados pelo racismo, inesperado sucesso é um exemplo importante.

A autora não conseguiu se manter na cena literária por muito tempo, dentre outras coisas, porque seu público não estava interessado na escritora, poeta e compositora Carolina, mas na favelada que vendia pobreza, miséria e fome. Estavam confortáveis com a ideia de que o produto da favela foi um documento sociológico e com a possibilidade de vivenciarem, em alguma medida, o exotismo da pobreza.

Fato semelhante ocorreu com autores como Paulo Lins e Ferréz, os quais foram sempre instados a manterem em seus textos os mesmos tons e temáticas de suas obras de maior sucesso - Cidade de Deus e Capão Pecado, respectivamente. Em entrevista ao professor Mário Medeiros, publicada no livro Polifonias Marginais, Ferréz fala um pouco sobre essa experiência como escritor, segundo ele, após a publicação de Capão pecado, "alguns editores falaram que eu tive sorte, que eu não era escritor [...] Muita gente falou 'Não, faz o [Capão pecado] Dois, faz o [Capão pecado] Três e tal'" (Peçanha et alii 2015: 70). No mesmo livro, também em entrevista a Mário Medeiros, Paulo Lins afirma:

A literatura brasileira só fala de pobre. Sempre falou, Guimarães Rosa, Graciliano Ramos, José Lins do Rego... Mas falar de pobre não é dar voz ao pobre. Eu nunca li o livro dela [Carolina Maria de Jesus]. Gostaria de ler. Nunca li. Muita coisa pra ler [...]

É o seguinte, o pessoal quer que você faça uma coisa que tenha política, que tenha isso, que tenha aquilo, que tenha sociologia, que tenha posição ideológica. Não pensei nisso, não achei necessário. Eu queria fazer literatura. Eu queria ser igual Dostoiévski. (idem: 70)

A reflexão de Paulo Lins é fundamental para pensarmos o lugar dessa produção nos estudos literários e Peçanha (2006) aprofunda o debate ao falar sobre a recepção do livro de Ferréz:

O romance não foi saudado como acontecimento literário, tampouco foi lançado sob o aval de algum crítico renomado, mas movimentou o interesse da imprensa que buscou evidenciar mais os aspectos sociológicos relacionados à produção do que as características da própria obra. Ferréz despontava, então, como exceção cultural de um dos locais da cidade mais associado à violência. (idem: 15)

No mesmo estudo, Peçanha nos lembra que, para contestar essa ideia corrente de que tanto Ferréz quanto Paulo Lins são exceções à regra da periferia inculta e selvagem - assim como Carolina Maria de Jesus já havia sido considerada nos anos 1960 -, em 2001 Ferréz inicia uma série de publicações com escritoras e escritores periféricas/os. ${ }^{2}$ Esse pode ser considerado um marco para uma importante mudança na cena literária nos últimos tempos: o movimento de literatura marginal/periférica. Além disso, o aumento de estudantes, professoras/es, pesquisadoras/es e ativistas negras e negros nas universidades, por meio principalmente das políticas afirmativas e de cotas, também contribuiu sobremaneira para aumentar o acesso, a apreciação e a pesquisa sobre a literatura negra. 
Cadernos de Literatura Comparada

Quem (não) tem medo da literatura negra?

Infelizmente, esse processo esbarra em um longo histórico de tradições racistas e elitistas que dificultam, sob os argumentos mais descabidos, como já verificamos em Abreu (2006), a circulação e a entrada dessas obras no hall da fama do cânone literário e, até mesmo, que sejam consideradas propriamente literárias. Para melhor compreendermos tais posturas, é fundamental aprofundar nossos conhecimentos sobre as relações de poder envolvidas na construção dessas ideias e na necessidade de manutenção do poderio hegemônico sobre a literatura e a cultura de modo geral.

\section{Nacionalismo, Miscigenação e Genocídio}

Na América, nem sempre encontrávamos as palavras. Só quando estávamos sozinhos falávamos com nossas vozes reais. Quando estávamos sozinhos, convocávamos os cavalos das nossas línguas e subíamos em suas costas e galopávamos deixando os arranha-céus para trás, sempre relutávamos em descer de novo. (Noviolet Bulawayo)

Vimos que, a escolha do cânone não é baseada unicamente na análise do texto e na identificação de sua suposta literariedade imanente, sendo contemplados com a imortalidade apenas aqueles que se encaixem nesse critério irrevogável. Há disputas de poder em jogo que vão muito além das bibliotecas, editoras, escolas e universidades - espaços já bastante conflituosos por si só. Como bem apontou Paulo Lins, falar sobre pobre não é o mesmo que dar voz ao pobre, pois isso implicaria negociar posições de comando e autoridade historicamente defendidas pelos grupos dominantes. A partir das reflexões de Moretti (2000) sobre os pontos de convergência ou "conciliação" entre a produção literária ocidental e a não ocidental podemos pensar outro aspecto extremamente relevante dessas disputas:

\footnotetext{
Permitam-me agora acrescentar algumas palavras sobre o termo "conciliação" - com o qual me refiro a algo ligeiramente diverso do que Jameson tinha em vista na sua Introdução a Karatani. Para ele, a relação é fundamentalmente binária: "os modelos formais abstratos da construção do romance ocidental" e "o material cru da experiência social japonesa" - forma e conteúdo, basicamente. Para mim, é antes um triângulo: forma estrangeira, material local e forma local. Simplificando um pouco: enredo estrangeiro, personagens locais e ainda voz narrativa local: e é precisamente nessa terceira dimensão que esses romances parecem ser mais instáveis - mais incômodos. (idem: 178-179)
}

Assis (2021) retoma a obra de Spivak (2010) e a grande questão sobre a possibilidade de o subalterno ter voz em uma sociedade que, historicamente, o silencia de diferentes formas para pensar esse incômodo com a voz narrativa local. Essa voz local ou a reivindicação do subalterno por assumir o lugar de fala em assuntos que cabem somente a ela/ele ou ainda a luta para sair da condição de objeto para a posição de sujeito e agente da própria história "vem se configurando como um grande problema, sobretudo quando falamos de autoria negra" (idem: 344): 
Em um mundo no qual, até poucas décadas, regimes segregacionistas eram defendidos com base em argumentos pseudocientíficos que questionavam a humanidade de sujeitos negros, a ideia de vê-los (des)construindo padrões estéticos e questionando conhecimentos e metodologias imperiais parece insuportável e insustentável. Não se trata mais apenas de abordar a temática negra, mas sim de conhecer a perspectiva histórica, crítica e cultural do próprio povo negro a respeito de si e de seu lugar na sociedade. (ibidem)

Além disso, também precisamos considerar suas propostas e modelos de relações sociais, econômicas, culturais e afetivas, bem como a ainda mais assustadora possibilidade de vê-las implantadas. A autora ressalta, ainda a importância de pensarmos sobre qual é esse local, a que chamam pátria, ou como é construído o sentimento de nacionalidade em sujeitos cujos vínculos com o novo território foram forjados "sob a égide da escravidão e, consequentemente, da exclusão social e da reificação, inerentes a ela" (idem: 345). Assis aponta as limitações de pensar a literatura desses povos a partir, apenas, de uma perspectiva nacionalista e, nesse sentido Gilroy oferece importante reflexão para aprofundarmos o debate:

Em oposição às abordagens nacionalistas ou etnicamente absolutas, quero desenvolver a sugestão de que os historiadores culturais poderiam assumir o Atlântico como uma unidade de análise única e complexa em suas discussões do mundo moderno e utilizá-la para produzir uma perspectiva explicitamente transnacional e intercultural. (2012: 57)

Nesse sentido, "o Atlântico Negro representaria uma alternativa para as posturas teóricas mais recorrentes no que se refere ao debate sobre as produções culturais e sociabilidades negras" (Assis: 345). No entanto, Gilroy alerta para alguns conceitos importantes e polêmicos quando pensamos na construção de identidades e culturas em contextos diaspóricos:

Seja qual for sua filiação à direita, esquerda ou centro, os grupos têm regressado à ideia de nacionalismo cultural, a concepções super integradas de cultura que apresentam as diferenças étnicas como uma ruptura absoluta nas histórias e experiências do povo "negro" e do povo "branco". Contra essa escolha se impõe outra opção mais difícil: a teorização sobre crioulização, métissage, mestizage e hibridez. Do ponto de vista do absolutismo étnico, essa seria uma ladainha de poluição e impureza. Esses termos são maneiras um tanto insatisfatórias de nomear os processos de mutação cultural e inquieta (des)continuidade que ultrapassam o discurso racial e evitam a captura por seus agentes. (idem: 35)

Podemos ver que, do ponto de vista do nacionalismo cultural, as diferenças étnicas são lidas como uma ameaça à unidade nacional. Porém, é importante lembrar que

As culturas nacionais são uma forma distintivamente moderna. A lealdade e a identificação que, numa era pré-moderna ou em sociedades mais tradicionais, eram dadas à tribo, ao povo, à religião e à região, foram transferidas, gradualmente, nas sociedades ocidentais, à cultura nacional. As diferenças regionais e étnicas foram gradualmente sendo colocadas, de forma subordinada, sob aquilo que Gellner chama de 
Cadernos de Literatura Comparada

Quem (não) tem medo da literatura negra?

"teto político" do estado-nação, que se tornou, assim, uma fonte poderosa de significados para as identidades culturais modernas. (Hall 2006: 49)

Segundo Hall, a formação de uma cultura nacional contribui para a universalização de saberes, graças, dentre outras coisas, à imposição da língua do colonizador como idioma oficial, que também servirá de base para a alfabetização dos povos colonizados. Essa homogeneização cultural, supostamente, faz com que a nação possa representar todas/os que a compõem, independente de gênero, raça, etnia, crença religiosa etc. Tal perspectiva é uma romantização da ideia de "crioulização, métissage, mestizage e hibridez", que dissimula os inúmeros atos de violência e coerção empreendidos para garantir o apagamento de toda e qualquer manifestação subjetiva ou modelo de organização social que destoasse da proposta de ordem e cultura nacional imposta pela dominação.

Como apontamos anteriormente, nos interessa pensar sobre o local de onde ecoa a voz de pessoas negras, dominadas por ideias de nacionalidade baseadas na violência e desprezo a suas histórias e culturas, tiradas de seus territórios originais e reterritorializadas num cárcere que quiseram lhes convencer a chamar de pátria. Importante lembrar que a ideia de cultura e identidade nacional proposta pelo ocidente sempre tendeu a

abordar a identidade não em termos de pertença mútua (co-pertença) a um mesmo mundo, mas antes na relação do mesmo ao mesmo [...] Em contrapartida, interessa compreender que, como consequência directa desta lógica de autoficção, de autocontemplação e, sobretudo, de enclausuramento, o Negro e a raça têm significado para os imaginários das sociedades europeias, a mesma coisa. Designações primárias, pesadas, perturbadoras e desequilibradas, símbolos de intensidade crua e de repulsa. (Mbembe 2017: 10)

Nesse contexto, como seria possível aceitar que sujeitos negros - imaginados e socializados a partir de percepções pautadas em "designações primárias, pesadas, perturbadoras e desequilibradas" - seriam capazes de criar literatura? Seria, no mínimo, absurdo pensar em pessoas negras protagonizando a produção de uma manifestação artística a qual "corresponde a uma necessidade universal que deve ser satisfeita sob a pena de mutilar a personalidade, porque pelo fato de dar forma aos sentimentos e à visão do mundo ela nos organiza, nos liberta do caos e, portanto, nos humaniza" (Candido 2004: 122).

Nessa perspectiva, o reconhecimento e aceitação da literatura negra no cânone seria oferecer poder para essas pessoas de dar forma a sentimentos e visões de mundo até pouco tempo inimagináveis entre esses sujeitos. Segundo Slenes. "associar escravos e gado - não apenas como semoventes, categoria codificada em lei, mas também como seres sexualmente desregrados - era comum na época" (2011: 142). Nesse livro, o autor apresenta um estudo sobre como a família negra escravizada foi sendo deturpada e impossibilitada pela historiografia até meados do século XX.

Embora em seu trabalho Slenes desconstrua essa sempre reatualizada ideia de que a escravidão tornou o povo negro irremediavelmente selvagem e, portanto, inapto para o amor, ainda 
hoje estereótipos relacionados à sexualidade desregrada e incapacidade de criar vínculos afetivos duradouros permeiam o imaginário, as epistemologias e as literaturas em todo o mundo.

Tais ideias foram sendo pensadas e, de alguma forma, implementadas, com mais ênfase a partir do fim dos regimes escravocratas, quando, no mundo todo, as ideias sobre superioridade e inferioridade racial tornaram-se ainda mais fundamentais para garantir a pureza das nações ocidentais. Pensamentos de estudiosos como o médico italiano Cesare Lombroso passaram a influenciar grandemente as políticas públicas voltadas para o controle racial e manutenção da pureza étnica branca:

no bojo das teorias raciais, naquele momento, se sustentava que, considerada a inferioridade ontológica, intrínseca, das raças asiáticas, negras e indígenas, qualquer tipo de mestiçagem, qualquer tipo de mistura entre a raça pura, a raça ariana e as raças inferiores, significava degenerescência. Essa era uma das vertentes das teorias raciais: a teoria da degenerescência da mestiçagem. (Cásseres 2020: 136-137)

No entanto, como aponta Cásseres (2020), no Brasil, as teorias sobre a degenerescência da mestiçagem não foram aceitas como base da política racial, como em outros países, dentre outras coisas pelo fato de, ao final do século XIX, a população negra representar $72 \%$ do contingente populacional do país. Diante disso, os dirigentes brasileiros acabam adotando as teorias da mestiçagem, ou seja, "as teorias do branqueamento vão aceitar a mestiçagem e projetar o Brasil como uma nação branca, uma nação que seria capaz de assimilar o elemento negro e o elemento indígena" (idem: 136).

Ainda houve tentativas de defender políticas baseadas na degenerescência da mestiçagem no Brasil. O médico Nina Rodrigues foi um dos grandes defensores dos males irremediáveis da miscigenação:

As causas reais das manifestações mórbidas ou de degenerescência estudadas na população de Serrinha devem ser mais longínquas e mais poderosas, e essas causas não são outras senão as más condições nas quais se efetivaram os cruzamentos raciais dos quais saiu a população da localidade analisada.

O cruzamento de raças tão diferentes antropologicamente, como são as raças branca, negra e vermelha, resultou num produto desequilibrado e de frágil resistência física e moral, não podendo se adaptar ao clima do Brasil nem às condições da luta social das raças superiores. (Rodrigues 2008[1899]: 1161)

Na literatura, Monteiro Lobato, bastante ciente do papel fundamental de sua arte na formação do povo e consolidação de ideologias, escreveu um verdadeiro manual, traduzindo, em linguagem popular e agradável, as complicadas ideias defendidas por estudiosos de diferentes áreas. Seu romance de ficção científica, $O$ choque das raças ou 0 presidente negro, publicado em 1926, faz uma crítica feroz à miscigenação e seus grandes riscos ao domínio branco e aponta a esterilização em massa da população negra, nos EUA, diante da eleição de um presidente negro no país, no ano de 2228, como uma saída para manutenção da ordem genocida implantada no país. 
Assim é anunciada a medida para lidar com a raça negra, finalmente exterminando suas possibilidades de reprodução: "estava lavrada a sentença de ponto final do negro na América? Sem verborreia, sem inútil dispêndio de retórica, sem citação dos gros bonnets da etnologia e da sociologia, a Suprema Convenção da Raça Branca traçara o diagnóstico e dera o remédio exato" (Lobato 1979: 141-142).

O livro foi rejeitado nos Estados Unidos e as ideias de segregação e extermínio direto foram substituídas, no Brasil, pelo genocídio por meio do branqueamento ou, como preferem os espíritos mais sensíveis ou hipócritas: miscigenação.

Embora a ideia da mestiçagem possa parecer mais palatável quando comparada à da degenerescência, em ambas fica evidente o desejo de exterminar a cultura, o fenótipo, o corpo negro. Do mesmo modo, a suposta proteção do "teto do estado-nação", problematizado por Hall (2006), não representa outra coisa, para esses povos, senão outra faceta do genocídio, ao negar língua, cultura, crenças, pertencimento, ancestralidade, num patente processo de epistemicídio (Carneiro 2005).

Nesse sentido, a ideia de uma identidade nacional, que abrange e representa todo o conjunto da população, não parece adequada ao povo negro, a quem a própria existência nesses territórios foi imposta, pensando nos povos da diáspora, ou, no caso dos povos africanos, estão ligados a uma territorialidade definida por repetidos processos violentos de colonização. Diante disso, o pertencimento racial parece se sobrepor a essas ideologias e mesmo as constantes tentativas de dividir e dizimar, de diferentes formas, esses povos e culturas vêm falhando miseravelmente. Como nos fala bell hooks:

Penso nos negros encontrando uns aos outros num espaço distante das diversas culturas e línguas que os distinguiam uns dos outros, obrigados pelas circunstâncias a achar maneiras de falar entre si num "mundo novo" onde a negritude ou a cor escura da pele, e não a língua, se tornariam o espaço da formação de laços. (hooks 2013: 225)

Literatura e amor negro: desobediência estética, epistêmica e afetiva

Eu plantei um pé de amor

E nasceu mandacaru

Tão forte, tão belo, tão áspero

Que eu não pude colher frutos...

Mas deu sombra e água fresca (Dinha)

Como vimos, mestiçagem, hibridização e outros conceitos correlatos quase sempre tentam ocultar a estratégia genocida de extermínio da cultura e da presença negra. Em nome da construção de uma identidade nacional coerente e coesa, condizente com modelos e valores eurocêntricos, as culturas, tradições e afetos não hegemônicos são, aos poucos exterminados e, com eles, se vão também os povos que os representam. Aquilo que não foi possível roubar 
- através de constantes processos de apropriação cultural que "releem" as tradições e práticas culturais negras para serem vendidas e consumidas pela branquitude - foi demonizado, criminalizado, subalternizado com o objetivo de manter no ostracismo qualquer prática dissonante das dominantes.

A crença na miscigenação como redentora e caminho para aceitação social causou muitos danos à autoestima da população negra bem como à possibilidade real de constituir família e criar laços afetivos duradouros entre pessoas negras. Nesse contexto, casar-se com uma pessoa branca é a única forma de, finalmente, fazer parte, estar inserida/o na sociedade e poder vivenciá-la de maneira próxima ao que é oferecido a um ser humano:

Não quero ser reconhecido como negro, e sim como branco.

Ora - e nisto há um reconhecimento que Hegel não descreveu - quem pode proporcioná-lo, senão a branca? Amando-me ela me prova que sou digno de um amor branco.

Sou amado como um branco. Sou um branco.

Seu amor abre-me o ilustre corredor que conduz à plenitude...

Esposo a cultura branca, a beleza branca, a brancura branca.

Nestes seios brancos que minhas mãos onipresentes acariciam, é da civilização branca, da dignidade branca que me aproprio. (Fanon 2008: 69, grifo do autor)

Fanon nos mostra um dos aspectos mais dolorosos das muitas feridas coloniais que ainda precisam ser curadas, o medo de ser eternamente inculto, horrendo, indigno e a certeza de que apenas a herança genética superior e a aceitação brancas são capazes de oferecer isso. Não é o "teto do estado-nação", não são as políticas afirmativas, quando uma pessoa negra acolhe o mito da miscigenação redentora para si, quando ela sucumbe às pressões dos discursos animalizantes sobre seus iguais, em seu imaginário, nada além do corpo branco, do amor branco poderá salvá-la.

Não são poucos os exemplos que demonstram a necessidade da presença branca para a existência do sentimento amoroso entre pessoas não brancas. Assis (2020) destaca aspectos fundamentais das relações entre Iracema e Martim, em Iracema, e entre Peri e Ceci, em $O$ Guarani, ambas obras de José de Alencar, nas quais vemos começar a se desenhar o mito da democracia racial, por meio da romantização dos estupros durante o período colonial.

Começamos a ver surgir o valente povo brasileiro, que o romantismo pretendia construir, simbolizado por Moacir - filho de Iracema e Martim - , nascido da dor e do sofrimento de sua mãe, que sofre a perda do amor de Martim, das origens e da família ancestrais e precisa ser sacrificada para que o pecado original, por meio do qual se origina o povo brasileiro, pudesse ser expurgado. O terrível pecado do sexo sem o sacramento da Igreja ou reconhecimento do Estado e o mais terrível de todos, a relação com uma mulher pagã e consciente de seus desejos impossibilita a vivência amorosa que se esperava na nação a ser erigida. Segundo Hall, um dos exemplos de narrativa da cultura nacional 
Cadernos de Literatura Comparada

Quem (não) tem medo da literatura negra?

é a do mito fundacional: uma estória que localiza a origem da nação, do povo e de seu caráter nacional num passado tão distante que eles se perdem nas brumas do tempo, não do tempo "real", mas de um tempo "mítico". Tradições inventadas tornam as confusões e os desastres da história inteligíveis, transformando a desordem em "comunidade". (2006: 54-55)

Podemos dizer que a lenda de Iracema funciona como uma dessas narrativas, tomando para si, inclusive, fortes relações com o mito cristão da responsabilização da mulher, Eva, pelo exílio do homem para fora do paraíso e as dores do parto como castigo pelo pecado cometido por ela. O homem branco, no caso do romance alencariano, e a religião cristã funcionam como redentoras do pecado pagão e devolve a grandiosidade histórica, perdida "nas brumas do tempo", ao povo miscigenado, chamando de comunidade o desastre histórico que foram as relações entre colonizador e colonizado.

No caso de relações inter-raciais entre negras/os e brancas/os, as histórias são ainda mais desastrosas, como nos mostrou Fanon (2008). Noguera (2020) faz uma interessante comparação entre $O$ Cortiço, de Aluísio Azevedo, e Anjo Negro, de Nelson Rodrigues. Em ambas as narrativas notamos que as personagens negras, longe de proporcionarem qualquer possibilidade de redenção e avanço racial, acabam por subverter a pureza branca, relação mais nítida na figura de Rita Baiana, no romance de Azevedo, ou as relações são sempre conturbadas e com consequências nefastas, como na obra de Rodrigues. Nesse sentido, podemos dizer que as ideias de degenerescência da mestiçagem, embora abolidas do projeto político de nação, ainda povoam o imaginário e inspiram a literatura nacional.

Porém, como dissemos anteriormente, a política genocida de branqueamento e de extermínio simbólico do negro, por meio da desqualificação de suas características identitárias, tem falhado, afinal, ainda estamos aqui! Após séculos de ataques, ainda lutamos não apenas contra o genocídio empreendido pela polícia, que faz homens e meninos negros tombarem diariamente, mas também contra o massacre psicológico causado por ofensas, descrédito, desprezo, desconfiança, brutalização, demonização etc.

Desde o século XIX, a literatura negra vem produzindo material para combater essas ideias e mostrar possibilidades de amor e beleza entre pessoas negras, além de desmistificar a romantização dos estupros. Uma das estratégias mais recorrentes está na valorização da família negra e da gestação como um caminho para manter vivo não apenas o fenótipo negro, mas também sua cultura e história verdadeiras.

O poema "Sabina", de Machado de Assis, é um bom exemplo para pensarmos as relações inter-raciais, sem apagar a violência sofrida pela mulher negra, mas principalmente ressaltando a força do amor materno e a sinceridade de seus sentimentos, apesar dos horrores da escravidão e da crueldade brancas. A ironia clássica de Machado de Assis se faz presente ao longo de todo o texto, como quando satiriza a poesia clássica e, em alguma medida, também o culto à beleza branca "Um vero Adônis, como aqui diria / Algum poeta clássico, daquela / Poesia que foi nobre, airosa e grande / Em tempos idos, que ainda bem se foram..." (Assis 1994: 43). 
O autor também rebaixa os sentimentos do jovem, ao referir-se ao coração do moço como "[...] tão volúvel / Como a brisa que passa ou como as ondas" (idem: 47). A jovem mucama alimentava uma paixão distante e desesperançada pelo jovem senhor e quis a (má) sorte que um dia ele a visse nadando no rio e declarasse seu amor a ela. Porém, embora as doces palavras do jovem remetessem a um amor puro e apaixonado, a voz poética não deixa dúvidas sobre suas verdadeiras intenções, como quando descreve o desejo e não amor que sente ao ver a moça ou a indiferença com que volta a sua rotina de estudos, deixando para trás a mucama apaixonada:

\footnotetext{
E com que olhos de pena e de saudade

Viu ir-se um dia pela estrada fora

Otávio! Aos livros torna o moço aluno,

Não cabisbaixo e triste, mas sereno

E lépido. Com ela a alma não fica

De seu jovem senhor. Lágrima pura,

Muito embora de escrava, pela face

Lentamente lhe rola, e lentamente

Toda se esvai num pálido sorriso

De mãe (idem: 46)
}

No excerto acima, Machado não apenas desnuda a indiferença do senhor branco aos afetos e a importância da entrega feita pela jovem donzela, mas também ressalta a verdade e a beleza dos sentimentos da jovem, além de apresentar o elemento determinante para torná-la ainda mais forte e viva: a maternidade.

O poema pode ser, em alguma medida, aproximado ao texto de Alencar, Iracema, por exemplo, quando pensamos nas semelhanças no encontro dos casais. Nas duas histórias o homem branco se encanta pela "mulher de cor" - para usar a expressão de Fanon - à beira de um rio, diante de um corpo perfeito, "Talhado pela mão da natureza / Sobre o modelo clássico" (idem: 44) ou, como diria Alencar (1991: 07), "a virgem dos lábios de mel, que tinha os cabelos mais negros que a asa da graúna, e mais longos que seu talhe de palmeira". No entanto, ao contrário do desfecho trágico e do forte cunho moralista e cristão do romance indianista, Machado ressalta a força que vem do fruto de um sentimento verdadeiro, por parte de Sabina, sem deixar de fazer a crítica à incapacidade do homem branco de percebê-lo ou valorizá-lo.

No poema machadiano, as características frágeis e fúteis de Otávio não são valorizadas, como acontece com a figura de Martim, cujo amor e caráter são igualmente frágeis, sobretudo se comparados aos sentimentos e personalidade de Iracema, porém Alencar tenta valorizar a bravura do colonizador e Machado o coloca na posição de inconstância e imaturidade, destacando, assim, a força e a beleza do amor da escravizada.

Sabina, por fim, pensa em se matar, mas é o amor que a salva, o amor pela vida que carrega. Essa temática está presente em muitas outras obras de diferentes formas. No poema 
machadiano, notamos ainda a ideia da miscigenação como pano de fundo para o sentimento da moça e o fruto de seu amor também será ainda mais próximo da brancura - visto que a moça é descrita como mestiça - porém seu sentimento surge independente da convivência com o branco e sua experiência de abandono e decepção não foi capaz de apagá-lo.

Ainda no século XIX, Maria Firmina dos Reis, no primeiro romance abolicionista brasileiro, Úrsula, nos traz o primeiro relato na perspectiva de uma mãe africana sobre a importância desse sentimento. Mãe Suzana dá voz a todas as mulheres negras escravizadas ao descrever seus sofrimentos com o processo de sequestro e cárcere que a trouxe e manteve no Novo Mundo, deixando nítida a humanidade inabalada pelos terrores da escravidão. A saudade, as inúmeras perdas, a solidão, nada foi capaz de impedi-la, por exemplo, de amar Túlio como seu filho. Em seu conto "A Escrava", Reis nos conta outra história de profundo amor entre mãe e filho surgida no seio da senzala.

Luís Gama também cantou a beleza da mulher negra e o amor pela mãe. Ao descrever a mulher amada com características físicas mais próximas de mulheres africanas, Gama aponta para uma musa negra, para um corpo negro capaz de inspirar amor e não apenas desejo "as madeixas crespas negras, / sobre o seio lhe pendiam [...] Não te afastes lhe suplico / És do meu peito rainha" (Gama 1974: 29). No poema "Minha mãe", o feitio dos traços negros e a origem africana são novamente ressaltados "Era mui bela e formosa, / Era a mais linda pretinha, / Da adusta Líbia rainha" (idem: 139).

Mota (2018) nos oferece uma obra inteira desenvolvendo como o amor e a família são determinante para a sobrevivência do povo negro. Além de colocar a maternidade no centro da luta antirracista, a poeta também ressalta a importância da família negra, homens e mulheres negros e negras unidas em luta por humanidade. Segundo Assis (2018: 11), em Zero a zero: 15 poemas contra o genocídio da população negra, "a maternidade, mais que um ato de amor, passa a ser a ação mais revolucionária e ameaçadora para o projeto racista de genocídio físico, emocional e epistemológico do negro".

\author{
De olho, o cachorro gordo percebe \\ nas barrigas da família \\ pequenas revoluções \\ repondo a morte com vida. \\ Repondo Ricardo a Ricardo \\ Rivaldo a Rivaldo \\ dobrando os soldados \\ perpetuando a ira \\ e a lira (Mota 2018: 28)
}

O poeta Akins Kinte acrescenta aspectos interessantes das relações amorosas negras. Em seus poemas eróticos e lírico-amorosos, bem como em alguns de seus contos, o autor descreve relações marcadas por situações de marginalidade, por uma realidade dura e cheia de perdas, 
que, ao contrário de enfraquecer os vínculos os torna mais fortes e determinantes, pois, dentre outras coisas, garantem a existência material e psicológica das famílias. Em sua obra o homem negro também assume um lugar de humanização historicamente negado e até hoje impensável pela maioria.

O mesmo lugar de humanidade masculina negra pode ser visto na obra de Conceição Evaristo. Em obras como Becos da memória e Ponciá Vicêncio temos protagonistas femininas potentes e hipnotizantes, mas a sensibilidade e criticidade com que constrói as personagens masculinas também inquieta e emociona. Figuras como Tio Totó e Bondade, de Becos da memória, nos mostram novamente como a violência e a pobreza não foram capazes de brutalizar esses homens.

Evaristo, assim como Toni Morrison, consegue nos fazer ver mesmo a violência desses homens com outros olhos. Não se trata de justificar ou dar desculpas, mas de entender que apesar de não conseguir superar o longo processo de animalização em suas relações sociais e afetivas, há sentimentos e conflitos terrivelmente dolorosos marcando a vida desses sujeitos, muitos dos quais sequer conseguem entender a própria masculinidade fora do signo da violência e da dor. Vemos isso, por exemplo, no marido de Ponciá, de Ponciá Vicêncio, que bebe e agride a esposa, bem como em Cholly, personagem de $O$ olho mais azul, de Toni Morrison, o qual comete o pior dos crimes ao estuprar e engravidar a própria filha.

Atos de violência, alcoolismo, criminalidade são as características mais recorrentes de personagens masculinos negros na literatura, no entanto, na literatura hegemônica branca há pouca ou nenhuma preocupação em retratar o que se passa na cabeça e no coração desses homens. Tampouco há a possibilidade real de enxergar amor em alguém com essa personalidade ou em um criminoso confesso, como vemos nos contos "Ana Davenga" e "Maria", do livro Olhos d'água, também de Conceição Evaristo:

Ela sabia o que o homem dizia. Ele estava dizendo de dor, de prazer, de alegria, de filho, de vida, de morte, de despedida. Do buraco-saudade no peito dele... Desta vez ele cochichou um pouquinho mais alto. Ela, ainda sem ouvir direito, adivinhou a fala dele: um abraço, um beijo, um carinho no filho. E, logo após, levantou rápido sacando a arma. (Evaristo 2016: 41)

É possível notar que possibilitar um diálogo franco e sensível entre homens e mulheres negros e negras, cada qual se reconhecendo um no outro, compartilhando o fardo de ser negro em um mundo racializado e racista, é um ponto central na superação das barreiras para o amor negro.

Portanto, se por um lado a literatura branca, hegemônica, reforça, historicamente, estereótipos, delimita sentimentos e relações, por outro, a literatura negra responde sempre à altura ao ódio semeado pelo racismo e (re)constrói afetos e famílias. Além de colocar em xeque o monopólio branco do amor, a literatura negra também apresenta uma nova proposta de vivência amorosa e fazer poético, pois

no amor cantado pela literatura negra não há idealizações, estabelecimento de padrões ou regras para 
Cadernos de Literatura Comparada

Quem (não) tem medo da literatura negra?

buscar uma prática social devidamente controlada e moldada de acordo com os interesses dominantes, mas sim uma obra baseada na observação da realidade dessas relações.

O lirismo, os afetos e a beleza dos textos e estórias contadas não provêm de um desejo fantasioso por perfeição e controle, como vimos se construir no projeto romântico de amor e identidade nacional. Tampouco há a descrença na possibilidade de vínculos e projetos coletivos e a longo prazo, presente, por exemplo, nas propostas naturalistas e realistas, em resposta ao idealismo romântico. A matéria na qual se inspira a literatura negra é a realidade do que as pessoas de fato são capazes de vivenciar e construir coletiva e objetivamente, através de seus afetos, desejos, sonhos e lutas, sem a busca de uma perfeição inalcançável, mas também distante do pessimismo determinista de boa parte da produção hegemônica. (Assis 2020: 15)

Historicamente, a literatura hegemônica elegeu cânones condizentes com seus interesses sociais e políticos, imortalizando obras que se tornaram fundamentais para a construção de uma imagem deturpada de sujeitos negros, reforçando o imaginário racista. Segundo Duarte (2013), a literatura do século XIX reduziu as personagens negras, quando apareciam, a coadjuvantes, vilões, limitadas aos estereótipos da sensualidade pecaminosa.

Assim como a literatura hegemônica levou para dentro de cada lar no mundo o ideal do amor verdadeiro, da família ideal, do casamento como símbolo da pureza e sacralidade do afeto entre duas pessoas, ela também instituiu que esse amor só poderia existir entre um homem e uma mulher - heteronormativo, portanto excluindo todo o grupo LGBTQIA+ da possibilidade de vivenciar o amor -; que essa família deveria representar os valores cristãos e burgueses homem superior à mulher - e que negros e negras não eram dignos desse sentimento.

Seja pela ausência ou pela estereotipização racista, o cânone literário sempre apresentou a ideia de que apenas por intermédio de uma pessoa branca seria possível a alguém não branco vivenciar o amor. Nesse sentido, a literatura negra representa muito mais do que a possibilidade de momentos de estesia, ela é o caminho para uma das mais importantes armas contra o genocídio da população negra: o amor negro, única maneira de resistir ao genocídio pelo branqueamento.

Não será possível superar o e sobreviver ao racismo sem a restauração da centralidade da família negra, sobretudo daquela família chamada de desestruturada por aquelas e aqueles que ainda vivem performando a família ideal, imaginária, dos românticos, da família de verdade, forjada no fogo das relações cotidianas, marcadas por questões materiais e enfrentamentos de toda sorte. No bojo dessa família, da deliciosa confusão de afetos conflitantes que permeiam as relações humanas, nasce, parafraseando a epígrafe dessa seção, o mandacaru tão forte, tão belo, tão áspero, sem frutos, muitas vezes, mas sempre oferecerá sombra e água fresca, que é o amor preto.

Essa é a matéria primordial da literatura que vem para desconstruir as convicções epistemológicas brancas, com um lirismo da realidade, o lirismo de libertação, de que nos fala Mota (2011). Uma literatura que rompe inclusive com os limites da própria língua imposta pelo opressor e recoloca a cor e a ancestralidade em lugar de destaque, reconhecimento e pertença. Uma literatura capaz de vencer a morte com vida. 


\section{NOTAS}

* Mariana Santos de Assis, Licenciada em Letras, Mestra em Linguística Aplicada e Doutoranda em Teoria e História Literária pela Universidade Estadual de Campinas, Unicamp. Professora da Prefeitura de São Paulo. Integra o Coletivo ILE ARA - Instituto Livre de Estudos Avançados em Religiões Afro-brasileiras. Atua nas áreas de Ensino de língua portuguesa; Letramentos; Multiletramentos; Literatura negra, marginal-periférica e negromarginal; Culturas não hegemônicas; Gênero e Raça.

${ }^{1}$ Em 1960 a literatura negra já contava em seu acervo de grandes obras de autoria negra como o primeiro romance abolicionista, que também foi o primeiro romance de autoria feminina, Úrsula, de Maria Firmina dos Reis, lançado em 1859; o fundador da Academia Brasileira de Letras e o principal e mais reconhecido escritor da literatura brasileira, Machado de Assis; além de outros grandes nomes que compõem o cânone nacional e outros que deveriam compor, como Cruz e Souza, Luiz Gama, Lima Barreto, Ruth Guimarães, Solano Trindade, entre tantas/os outras/os.

${ }^{2}$ Referência à edição especial da revista Caros Amigos, Caros Amigos/ Literatura Marginal, que contou com 3 volumes ou Atos, publicados, respectivamente, em 2001, 2002 e 2004.

\section{Bibliografia}

Abreu, Márcia (2006), Cultura letrada: literatura e leitura, São Paulo, Editora Unesp. Alencar, José de (1991), Iracema, São Paulo, Ática. Assis, Machado de (1994), Obra Completa, Rio de Janeiro, Nova Aguilar.

Assis, Mariana Santos de (2020), "Afetos interditos: racismo e literatura na construção do amor e da família" in Latinidades - Fórum Latino-Americano de Estudos Fronteiriços, Anais... <https://eventos.claec.org/index.php/ latinidades/latinidades2020/paper/view/2552> (último acesso em 29/12/2020).

-- (2021), "Rimar letrando ou letrar rimando: os saraus literários da periferia de São Paulo como agências de letramento", in Cultura política nas periferias: estratégias de resistência, São Paulo, Fundação Perseu Abramo (no prelo).

- - (2018), "Tecendo a luta e a lira: vida e morte na poesia de Dinha", in Mota, Maria Nilda de Carvalho (2018), Zero a zero: 15 poemas contra o genocídio da população negra, São Paulo, Edições Me Parió Revolução.

Cândido, Antônio (2004), "O direito à literatura", in Vários Escritos, São Paulo, Ouro sobre Azul. Carneiro, Sueli (2005), A construção do outro como não-ser como fundamento do ser, Tese (Doutorado em Educação junto à área de Filosofia da Educação), Universidade de São Paulo, São Paulo.

Cásseres, Lívia (2020), "O racismo como estruturante da criminologia brasileira", in Direitos humanos, saúde mental e racismo, Rio de Janeiro, Defensoria Pública do Estado do Rio de Janeiro, pp. 129-143. 
Duarte, Eduardo de Assis (2013), "O negro na literatura brasileira", in Navegações, v. 6, n. 2, pp. 146-153.

Eagleton, Terry (2006), Teoria da literatura: uma introdução, São Paulo, Martins Fontes.

Eckermann, Johann Peter (2016), Conversações com Goethe nos últimos anos de sua vida: 18231832, São Paulo, Editora Unesp.

Evaristo, Conceição (2016), Olhos d'água, Rio de Janeiro, Pallas.

Fanon, Frantz (2008), Pele negra, máscaras brancas, Salvador, EDUFBA.

Ferréz (2000), Capão Pecado, São Paulo, Labortexto.

Gama, Luís (1974), Trovas burlescas, São Paulo, Editora Três.

Gilroy, Paul (2001), O Atlântico Negro. Modernidade e dupla consciência. São Paulo, Rio de Janeiro, 34/Universidade Cândido Mendes - Centro de Estudos Afro-Asiáticos.

Hall, Stuart (2006), A identidade cultural na pós-modernidade, Rio de Janeiro, RJ: DP\&A.

hooks, bell (2013), Ensinando a transgredir: a educação como prática da liberdade, São Paulo, Editora WMF Martins Fontes.

Jesus, Carolina Maria de (1960), Quarto de despejo: diário de uma favelada, São Paulo, Círculo do Livro.

- (1961), Casa de alvenaria: diário de uma ex-favelada, Rio de Janeiro, Editora Paulo de Azevedo.

Lins, Paulo (1997), Cidade de Deus, São Paulo, Companhia das Letras.

Lobato, Monteiro (1979), o presidente negro, São Paulo, Brasiliense.

Mbembe, Achille (2017), Crítica da razão negra, Lisboa, Antígona.

Moretti, Franco (2000), "Conjeturas sobre a literatura mundial", in New Left Review, Londres.

Mota, Maria Nilda de Carvalho (2008), De passagem mas não a passeio, São Paulo, Global, [Dinha].

-- (2011), Lirismo de libertação: uma leitura de poemas africanos e afro-brasileiros, Dissertação de mestrado, Universidade de São Paulo, São Paulo.

-- (2018), Zero a zero: 15 poemas contra o genocídio da população negra, São Paulo, Edições Me Parió Revolução.

Nascimento, Abdias (1978), o genocídio do negro brasileiro: processo de um racismo mascarado, Rio de Janeiro, Paz e Terra.

Noguera, Renato (2020), "Fanon, O cortiço e Anjo negro: breve esboço sobre relações inter-raciais heterossexuais no contexto do racismo", in Direitos humanos, saúde mental e racismo, Rio de Janeiro, Defensoria Pública do Estado do Rio de Janeiro, pp. 49-56.

Noviolet Bulawayo (2014), Precisamos de novos nomes, São Paulo, Biblioteca Azul.

Peçanha, Érica / Ingrid Hapke / Lucía Tennina / Mário Medeiros (2015), Polifonias marginais, Rio de Janeiro, Aeroplano.

Peçanha, Érica (2006), Literatura marginal: Os escritores da periferia entram em cena, Dissertação (Mestrado em Antropologia Social) - Faculdade de Filosofia, Letras e Ciências Humanas da Universidade de São Paulo, São Paulo.

Reis, Maria Firmina dos (2004), Úrsula: A escrava, Florianópolis, Ed. Mulheres; Belo Horizonte, PUC Minas. 
Rodrigues, Raimundo Nina (2008), "Mestiçagem, degenerescência e crime", História, Ciência e Saúde, v. 15, n. 4, p. 1151-1182, <https://www.scielo.br/pdf/hcsm/ v15n4/ 14.pdf> (último acesso em 28/12/2020) [1899].

Said, Edward W. (2011), Cultura e imperialismo, São Paulo, Companhia das Letras.

Silva, Mário Augusto Medeiros (2013), A descoberta do insólito: Literatura negra e literatura periférica no Brasil (1960-20oo), Rio de Janeiro, Aeroplano, 2013.

Slenes, Robert W. (2011), Na senzala uma flor: esperanças e recordações na formação da família escrava, Campinas, Editora Unicamp.

Spivak, Gayatri Chakravorty (2010), Pode o subalterno falar?, Belo Horizonte, Editora UFMG.

WReC (2020), Desenvolvimento combinado e desigual: por uma nova teoria da literatura mundial, Campinas, SP, [Warwick Research Collective]. 